\title{
THE EFFECT OF STORAGE CONDITION ON VIABILITY OF LACTIC ACID BACTERIA IN PROBIOTIC PRODUCT
}

\author{
YUNI TRISNAWITA*, JANSEN SILALAHI, SITI MORIN SINAGA
}

Department of Chemistry, Faculty of Pharmacy, Universitas Sumatera Utara, Medan, Indonesia. Email: uyuntrisnawita13@gmail.com Received: 07 March 2018, Revised and Accepted:25 March 2018

ABSTRACT

Objective: The aim of this study was to determine the effect of storage condition on viability of lactic acid bacteria (LAB) in probiotic product.

Methods: Four different of probiotic products used were A (Lacto B), B (Rillus), C (Interlac), and D (Lacbon) containing single or mixed LAB. The product was stored at temperature of $4^{\circ} \mathrm{C}$ and $28^{\circ} \mathrm{C}$ for 28 days. Viability test of LAB was done by counting a number of colony bacteria that live on de man, Rogosa, and Sharpe Agar.

Results: The results of the study showed that counts of the LAB colonies in product A were less at the label $\left(5.04 \times 10^{7} \mathrm{cfu} / \mathrm{sachet}\right)$, whereas in products $\mathrm{B}, \mathrm{C}$, and D were matching with the label. Storage at a temperature of $28^{\circ} \mathrm{C}$ for 28 days showed significant loss on the viability of LAB in product $\mathrm{C}$ $(\mathrm{p}<0.05)$.

Conclucion: Storage temperature affecting on viability of LAB in probiotic product where storage at temperature $4^{\circ} \mathrm{C}$ is higher than $28^{\circ} \mathrm{C}$ for 28 days.

Keywords: Viability, Lactic acid bacteria, Storage condition, Probiotics, Product.

(C) 2018 The Authors. Published by Innovare Academic Sciences Pvt Ltd. This is an open access article under the CC BY license (http://creativecommons. org/licenses/by/4. 0/) DOI: http://dx.doi.org/10.22159/ajpcr.2018.v11s1.26574

\section{INTRODUCTION}

Probiotics is living microorganism that can give a beneficial effect on the health of the host when consumed in an adequate amount. The minimum dose of daily consumption of probiotic bacteria is $10^{7} \mathrm{cfu}$. Class of lactic acid bacteria (LAB) such as Lactobacillus, Streptococcus, and Bifidobacterium is commonly used as probiotic bacteria [1].

Some benefits of consuming probiotic bacteria are for antidiarrhea, antiallergic, reducing blood pressure, anticholesterol, immunomodulator, improving lactose intolerance, eradication helicobacter pylori, decrease irritable bowel syndrome, preventing vaginosis, and colon cancer [2].

In general, living probiotic bacteria are obtained from three sources: Fermented milk products, fermented foods or beverages, and pharmaceutical product such as capsules, powders, and tablets. The data on probiotic product labels informing the number of live bacteria (viability) should be accurate to ensure the safety and function of probiotic product [3].

There are three of four probiotic products containing Lactobacillus sp. sold on the market do not contain the number of bacteria which are in accordance with the packaging label, although their antibacterial activity against some pathogen bacteria remains active. There are three of four probiotic products and five of six commercial food products containing Lactobacillus sp. sold on the market do not contain the number of bacteria which are in accordance with the packaging label, although their antibacterial activity against some pathogen bacteria remains active $[4,5]$.

The viability of probiotic bacteria is influenced by some factors such as physiological conditions, toxic material, $\mathrm{pH}$, oxygen, water activity, nutrition, temperature, and storage time. Most probiotic product has a short lifespan, even when they are stored at low temperatures. This characteristic causes problem for both consumers and producers because the benefits of consuming probiotic bacteria are only obtained when probiotic bacteria are consumed in appropriate amounts [6].

The purpose of this study was to investigate the effect of storage condition on viability of LAB in probiotic product.

\section{MATERIALS AND METHODS}

\section{Materials}

Sample collection was done by purposive sampling methods. Samples used were four types of probiotic preparations containing single or mixed LAB purchased from pharmacies in the city of Medan, North Sumatra. Probiotic preparations used were A (Lacto B: Viable cell L. acidophilus, Streptococcus thermophiles, and Bifidobacterium longum $6.0 \times 10^{7} \mathrm{cfu} /$ sachet/1 g), B (Rillus: Viable cell L. plantarum, Bifidobacterium bifidum, and $S$. thermophilus $1.0 \times 10^{9} \mathrm{cfu} /$ tablet $/ 1.5 \mathrm{~g}$ ), C (Interlac: Viable cell Lactobacillus reuteri $1 \times 10^{8} \mathrm{cfu} /$ tablet/ $0.5 \mathrm{~g}$ ), and D (Lacbon: Viable cell Lactobacillus sporogenes $5 \times 10^{7} \mathrm{cfu} /$ tablet/0.25 g). Media used were de man, Rogosa, and Sharpe Agar (MRSA) and de man, Rogosa, and Sharpe Broth.

\section{EXPERIMENTAL DESIGN}

This experiment was carried out with storage temperature (Ts) at $4^{\circ} \mathrm{C}$ (Ts1 in refrigerator) and $28^{\circ} \mathrm{C}$ (Ts2 in incubator) and storage time (Ws) at $0,7,14,21$, and 28 days. All samples were stored in original packaging.

\section{ASSESSMENT OF VIABLE CELL NUMBERS OF PROBIOTIC PREPARATIONS}

Diverse $1 \mathrm{~g}$ of sample in $9 \mathrm{ml}$ of $0.9 \% \mathrm{NaCl}$ and homogenized of $10^{-1}$, then diluted the solution gradually to $10^{-10} .1 \mathrm{ml}$ of each dilution series and inserted it into a sterile Petri dish. Poured $15 \mathrm{ml}$ of MRSA media at $45^{\circ} \mathrm{C}$ into the Petri dish and homogenized. Incubated the solution at $37^{\circ} \mathrm{C}$ for $48 \mathrm{~h}$. Observed and counted the viable of LAB colonies grown on MRSA media using a colony counter. Dilution with the number of 30-300 colonies was used as the basis of the counts $[3,7]$.

\section{Statistical analysis}

Statistical analysis was made using one-way analysis of variance. The results were considered significantly different at $\mathrm{p}<0.05$. Furthermore, to compare the average results of each treatment, the test was continued using Tukey HSD analysis on the Statistic Product and Service Solutions 17.0 (SPSS) program $[3,8]$. 


\section{RESULTS}

Measurement of the viability of LAB in probiotic product $\mathrm{C}$ at $4^{\circ} \mathrm{C}$ and $28^{\circ} \mathrm{C}$ for 28 days was carried out by colony counter (Fig. 1), and the result of treatment is presented in Tables 1 and 2 and Fig. 2.

\section{DISCUSSION}

The number of LAB colonies contained in the product $\mathrm{A}, \mathrm{B}, \mathrm{C}$, and $D$ indicates that the number of LAB colonies grown on $B, C$, and $D$ product was in accordance with the number of $\mathrm{LAB}$ colonies listed on the label, but the number of $\mathrm{LAB}$ colonies that grow in the product A was lower than the number of LAB colonies listed on the label.

Storage at $4^{\circ} \mathrm{C}$ for 28 days did not cause a change in the number of colonies of $\mathrm{LAB}$ although the $\mathrm{LAB}$ of product A did not match with the label. The number of $L$. acidophilus bacterial colonies of fermented milk remained unchanged when kept at $4 \pm 1^{\circ} \mathrm{C}$ for 28 days $(>7 \log$ $\mathrm{cfu} / \mathrm{g})$. The number of L. plantarum bacterial colonies of food products stored at $4^{\circ} \mathrm{C}$ still showed good results compared to storage at $27^{\circ} \mathrm{C}$ for 7 weeks. Results from the previous study of four types of probiotic product containing Lactobacillus bacteria in Rillus, Lacbon, Lacto B, and Lacidophil using Plate Count Agar media conclude that only Lacto B product lower than mentioned at the label $[3,6,9]$.

The number of LAB colonies in product $\mathrm{C}$ dropped significantly when kept at $28^{\circ} \mathrm{C}$ for 28 days although still match with mentioned at the label. This is due to the temperature of $28^{\circ} \mathrm{C}$ which is the optimum growing temperature of $\mathrm{LAB}$ in controlled fermentation. The near expiration date of product $C$ from determined of date (November 2017) was another factor causing the significant decrease in the number of LAB colonies in product $\mathrm{C}$.

Previous research has shown that storage at $25^{\circ} \mathrm{C}$ (in the regulated room) for 4 weeks caused by a significant decrease in the number of $\mathrm{LAB}$ colonies from the Interlac product. The number of LAB colonies in
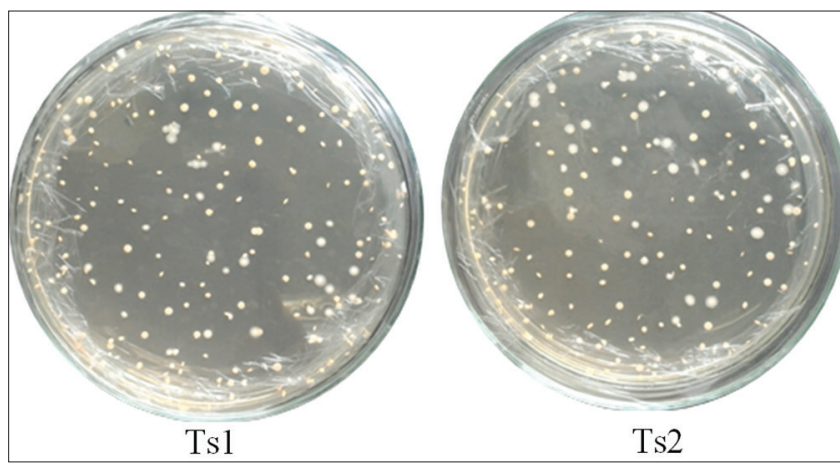

Fig. 1: The growth of lactic acid bacteria in preparations $\mathrm{C}$ (Interlac): Ts1 (stored at $4^{\circ} \mathrm{C}$ ), $\mathrm{Ts} 2$ (stored at $28^{\circ} \mathrm{C}$ )

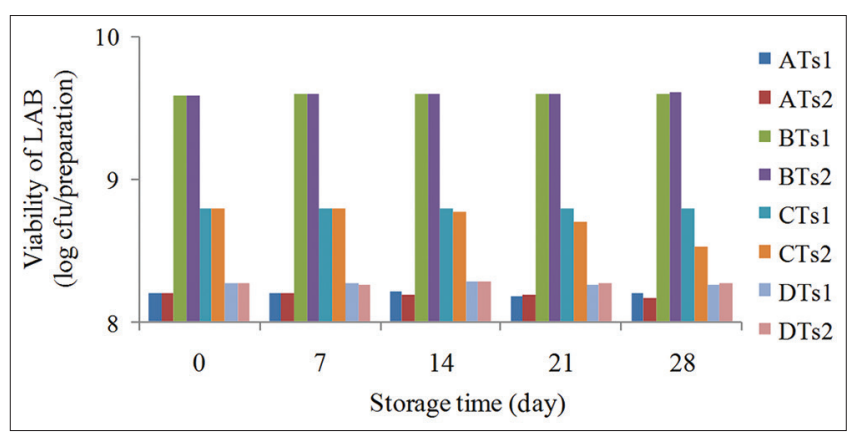

Fig. 2: The effect of storage condition on viability of lactic acid bacteria in probiotic product: A (Lacto B), B (Rillus), C (Interlac), D (Lacbon), Ts1 (stored at $4^{\circ} \mathrm{C}$ ), Ts2 (stored at $28^{\circ} \mathrm{C}$ )
Table 1: The effect of storage time at $4^{\circ} \mathrm{C}(\mathrm{Ts} 1)$ on viability of $\mathrm{LAB}$ in product

\begin{tabular}{llllll}
\hline Product & \multicolumn{5}{l}{$\begin{array}{l}\text { Actual viable cell numbers identified (cfu/ } \\
\text { preparation) at the storage time }\end{array}$} \\
\cline { 2 - 6 } & $\mathbf{0 ~ d}$ & $\mathbf{7 ~ d ~}$ & $\mathbf{1 4 ~ d}$ & $\mathbf{2 1 ~ d ~}$ & $\mathbf{2 8 ~ d ~}$ \\
\hline A (Lacto B) & $5.04 \times 10^{7}$ & $5.04 \times 10^{7}$ & $5.04 \times 10^{7}$ & $5.05 \times 10^{7}$ & $5.04 \times 10^{7}$ \\
B (Rillus) & $1.22 \times 10^{9}$ & $1.22 \times 10^{9}$ & $1.22 \times 10^{9}$ & $1.23 \times 10^{9}$ & $1.22 \times 10^{9}$ \\
C (Interlac) & $1.98 \times 10^{8}$ & $1.98 \times 10^{8}$ & $1.98 \times 10^{8}$ & $1.97 \times 10^{8}$ & $1.98 \times 10^{8}$ \\
D (Lacbon) & $6.48 \times 10^{7}$ & $6.03 \times 10^{7}$ & $6.05 \times 10^{7}$ & $6.05 \times 10^{7}$ & $5.90 \times 10^{7}$ \\
\hline
\end{tabular}

Values are the means of three replicates

Table 2: The effect of storage time at $28^{\circ} \mathrm{C}(\mathrm{Ts} 2)$ on viability of LAB in product

\begin{tabular}{llllll}
\hline Product & \multicolumn{5}{l}{$\begin{array}{l}\text { Actual viable cell numbers identified (cfu/ } \\
\text { preparation) at the storage time }\end{array}$} \\
\cline { 2 - 6 } & $\mathbf{0 ~ d}$ & $\mathbf{7 ~ d}$ & $\mathbf{1 4 ~ d}$ & $\mathbf{2 1 ~ d ~}$ & $\mathbf{2 8 ~ d}$ \\
\hline A (Lacto B) & $5.04 \times 10^{7}$ & $5.01 \times 10^{7}$ & $4.96 \times 10^{7}$ & $4.55 \times 10^{7}$ & $4.73 \times 10^{7}$ \\
B (Rillus) & $1.22 \times 10^{9}$ & $1.22 \times 10^{9}$ & $1.22 \times 10^{9}$ & $1.22 \times 10^{9}$ & $1.28 \times 10^{9}$ \\
C (Interlac) & $1.98 \times 10^{8}$ & $1.99 \times 10^{8}$ & $1.87 \times 10^{8}$ & $1.60 \times 10^{8 *}$ & $1.08 \times 10^{8}$ \\
D (Lacbon) & $6.48 \times 10^{7}$ & $6.03 \times 10^{7}$ & $6.03 \times 10^{7}$ & $6.00 \times 10^{7}$ & $5.93 \times 10^{7}$ \\
\hline
\end{tabular}

Values are the means of three replicates. ${ }^{*}$ indicates significantly lower

than the corresponding viable cell numbers stated on the label of the preparations $(\mathrm{p}<0.05)$

the probiotic product decreases with increasing storage temperatures that lead to cell dehydration, resulting in leakage of cells. The decrease in the number of LAB colonies can be caused by various factors affecting viability such as formulation or dosage form, water activity, nutrition, and temperature. Therefore, storage at high temperatures is not recommended for probiotic product [4].

\section{CONCLUSION}

The number of LAB colonies in product A did not match with the label, whereas the number of $\mathrm{LAB}$ colonies in product $\mathrm{B}, \mathrm{C}$, and $\mathrm{D}$ match with the label. Storage at $4^{\circ} \mathrm{C}$ for 28 days maintains the viability of LAB, while storage at $28^{\circ} \mathrm{C}$ for 28 days caused significantly decreased viability of $\mathrm{LAB}$ in product $\mathrm{C}$.

\section{ACKNOWLEDGMENT}

The authors would like to thank the Department of Chemistry, Faculty of Pharmacy and Department of Microbiology, Faculty of Math and Science, University of Sumatera Utara, Medan, Indonesia.

\section{CONFLICT OF INTEREST}

We declare that there is no conflict of interest.

\section{REFERENCES}

1. Malago JJ, Koninkx JF, Logar RM. Probiotic Bacteria and Enteric Infections. London New York: Dordrecht Heidelberg; 2011.

2. Junior WL, Ferrari IS, Souza JV, Barbosa AL, Costa MM, Menezes DR, et al. Principal criteria for selection of lactic acid bacteria for potential use as probiotics in foods. Afr J Microbiol Res 2015;9:671-86.

3. Carollina A. Determination of Total Plate Count (TPC) Bacterial in Probiotic Drugs. Thesis. Medan, Indonesia: Graduate School of the Faculty of Pharmacy, University of Sumatera Utara; 2015.

4. Begum A, Jakaria DM, Anisuzzaman SM, Islam M, Mahmud SA. Market assessment and product evaluation of probioticc ontaining dietary supplements available in Bangladesh market. J Pharm 2015;1:1- 5 .

5. Dharmasena MP. Assessment of Viability of Probiotic Bactericia in Non Dairy food Matrices Under Refrigeration Storage. Thesis. USA: Graduate School of the Food, Nutrition, and Culinary Sciences, Clemson University; 2012.

6. Utami F. The Effect of Temperature on Life Resistance of Bacteria on Probiotic Preparations. Thesis. Jakarta, Indonesia: Graduate 
School of the Faculty of Pharmacy, Islamic University of Syarif Hidayatullah; 2013.

7. Abbas HH, Mohammed SA, Shawkat DS, Baker YM. Effect of Lactobacillus sp. crude bacteriocin (CB) and cell-free supernatant (CFS) against $E$. coli growth and adherence on vaginal ephitelial cell surface. Int J Adv Res 2016;4:614-20.
8. Abdelsamei HM, Ibrahim EM, Sohaimy SA, Saad MA. Effect of Storage on the activity of the bacteriocin extracted from Lactobacillus Acidophilus. Benha Vet Med J 2015;28:216-22.

9. Ozcan T, Ersan LY, Bayizit AA, Delikanli B, Barat A. Survival of Lactobacillus spp. in fruit based fermented dairy beverages. Int J Food Eng 2015;1:44-9. 